\title{
A STRATÉGIAI HADIJÁTÉKOK SZEREPE A KATONAI FELSŐVEZETŐ-KÉPZÉSBEN'
}

\author{
DOI: $\underline{10.35926 / \mathrm{HSZ} .2020 .1 .7}$
}

ÖSSZEFOGLALÓ: A hadijáték (angol elnevezéssel wargame) mindig is különösen fontos szerepet játszott a hivatásos tisztképzésben. Döntéstámogató szerepe napjainkban sem tünt el, elég csak a NATO harcászati, sőt hadmüveleti szinten végzett törzsmunkájának keretet adó katonai döntéshozatal folyamatára gondolnunk, amelyben a cselekvési vázlatok alkalmazhatóságának értékeléséhez és a feladat-végrehajtás szinkronizálásához a hadijátékot összehasonlító-modellező módszerként használják. Ezek a módszerek hadmüveleti, hadászati, sőt stratégiai, azaz állami és katonai szövetségi szinten hozott döntések modellezésére is alkalmasak, természetesen a megfelelö szabályok lefektetésével.

A tanulmány bemutatja a hadijátékok és a hadtörténelem újra felfedezett kapcsolatát, az amerikai tengerészgyalogság vezérkari iskolája, a Marine Corps War College közelmúltban végrehajtott, wargame-alapú gyakorlatának tapasztalatait, valamint azok alkalmazási lehetőségeit a hazai katonai felsővezető-képzésben.

KULCSSZAVAK: hadijáték, wargame, stratégiai döntéshozatal, hadtörténelem, katonai felsővezető-képzés

\section{A HADIJÁTÉKOKRÓL ÁLTALÁBAN}

A hadijáték, avagy terepasztalos szimuláció egyidős a szervezett katonai erő létrejöttével. Királyok, hadvezérek, később tábornokok alkalmazták a hadmozdulatok hatékonyságának bemutatására, várható eredményeik modellezésére. Rendkívül olcsó, de hatékony módszer volt, amely gyors visszacsatolással és a megfelelö kiindulóállapot helyes meghatározásával valósághoz közeli eredményre vezetett. Később, a modern technika megjelenésével a számítógépes szimulációk kerültek előtérbe, s ennek hatására a hadijáték elvesztette legnagyobb előnyeit: olcsóságát, valamint kis erőforrás- és infrastruktúra-igényét.

A modern hadijáték a 19. század első felében született meg és a professzionális tisztképzésben jelent meg elöször. A porosz Kriegspielt (a hadijáték német elnevezése) a katonai döntéshozatal begyakorlására hozták létre, és az alakulatok térképi megjelenítésére épült. ${ }^{2}$ Hadijátékokat ezután sokáig csak a hadseregekben játszottak, de a 20. század elején a hobbi

\footnotetext{
1 Az írás az Innovációs és Technológiai Minisztérium ÚNKP-19-3-1-NKE-98 kódszámú Új Nemzeti Kiválóság Programjának szakmai támogatásával készült.

2 Pogácsás Krisztián föhadnagy: Terepasztalos parancsnoki hadijáték, avagy a parancsnoki döntéshozatal és harcászati szemlélet fejlesztésének eszköze. Seregszemle, XI. évf. 2013/2-3., 83. http://bocskaikonyvtar.hu/ images/emedia/PogacsasK_terepasztal2.pdf (Letöltés időpontja: 2019. 05. 04.)
} 
felhasználásukra is igény mutatkozott, így a civilek is megjelentek a hadijátékosok között. A hobbi hadijáték kezdetben egyszerủ ólomfigurákkal való stratégiai társasjátékot jelentett, ami a következő évtizedekben egy professzionális, de elsősorban nem katonák számára kiépült wargame iparág létrejöttét eredményezte. ${ }^{3}$

A katonai szervezetek hadijátékai napjainkra a bonyolultság, a komoly és költséges számítógépes infrastruktúrát és komplex programokat igénylő szimulációk irányába mozdultak el, s ez oda vezetett, hogy a rendelkezésre állásukat már a létrehozott rendszer önmaga korlátozta. Így tulajdonképpen a kiképzést és döntéstámogatást segítő hadijátékok nem tölthették be funkciójukat, mert csak rövid időre, komoly előkészítés és koordináció után lettek elérhetők a katonai szervezetek számára.

Az Amerikai Egyesült Államokban komoly kultúrája van a stratégiai döntéshozatali előkészítés során a civil tudás-, illetve kutatóközpontokhoz, más néven agytrösztökhöz ${ }^{4}$ (think-tank) kiszervezett elemzéseknek. Ezek a szervezetek gyakran saját wargame-alapú szimulációkat használnak fel az általuk közölt szakvélemény alátámasztására. Ezek közül az egyik legismertebb a kaliforniai székhelyű RAND Corporation, amely 2016-ban készített tanulmányt egy balti országok elleni lehetséges agresszió forgatókönyvéről és annak a NATO-ra gyakorolt hatásáról. ${ }^{5}$

Míg napjainkra a hadseregek hadijátékai jellegüknél fogva korlátozzák saját felhasználhatóságukat, a civil felhasználókat célzó társaik soha nem látott virágzásnak indultak. ${ }^{6}$ Ez természetes módon magával hozta a hadtörténelem népszerüsödését is, mert e tudományág ismerete elengedhetetlen a történelmi hadijátékok (historical wargame) által feldolgozott egyes történelmi korszakoknak és azok hadseregeinek vizsgálatához. Így az e téren mutatott tájékozottság közvetetten hozzájárult a gyakran erősen kompetitív játékokban való győzelemhez. Napjainkra tehát a hadtörténetírásra és a hadijátékokra a civil társadalom egyre bővülö rétegei részéről fokozódó igény mutatkozik.

A jelenleg kereskedelmi forgalomban kapható hadtörténeti témájú hadijátékok két nagy csoportja ismert. Az egyik az asztali hadijáték, angol elnevezéssel tabletop wargame. Közelebb van a harcászati szintủ, egy-egy katonát és harcjárművet vagy eszközt megjelenítő, az eredeti Kriegspiel döntéshozatali metódusában gyökerező terepasztalos játékhoz, és kezdetben a makettezés elterjedésének köszönhetően (azaz a járművek pontos, miniatürizált megjeleníthetőségének hála) kapott nagy népszerüséget. Napjainkban az olcsó,

3 Pogácsás: i. m. 84.

4 Tagjai nemritkán volt katonák, hírszerző szervezetek volt alkalmazottai, akik állami megrendelésre végeznek kutatásokat, adnak szakvéleményt bizonyos kérdésekben. Komoly infrastruktúrával és anyagi forrásokkal rendelkeznek, valamint nagy tudásbázist halmoztak föl.

5 Michael Johnson - David A. Shlapak: Reinforcing Deterrence on NATO's Eastern Flank. Wargaming the Defense of the Baltics. RAND, 2016. https://doi.org/10.7249/RR1253 (Letöltés időpontja: 2019. 05. 03.)

6 Ezt felismerve, a 2014-es eseményeket követően a NATO több hadserege - a modern elveknek megfelelően - a civil wargame-ek eredményeit is figyelembe véve elkezdte a saját hadijátékos „,szokásainak” újraszabályozását. Ez több, föleg iránymutatásokat tartalmazó kiadvány megszületéséhez vezetett. (Szándékosan kerültem a szabályzat kifejezést, mert a készítők is érzékelték, hogy a téma túlszabályozása a korábban érzékelt problémák megismétléséhez vezetne.) Ezek közül is kiemelkedik a brit Védelmi Minisztérium 2017-es kiadványa, a Wargaming Handbook. Development, Concepts and Doctrine Center (Ministry of Defence): Wargaming Handbook. LCSLS Headquarters and Operations Centre, Bicester, 2017. https://assets.publishing.service.gov. uk/government/uploads/system/uploads/attachment_data/file/641040/doctrine_uk_wargaming_handbook.pdf (Letöltés időpontja: 2019. 05. 05.)

7 Az asztali hadijáték a Tactical Decision Game (TDG) szintjén álló játék. A TDG nagyjából századszintig alkalmazható kiképzési eszközként. Pogácsás: i. m. 85. 
otthon is elérhető 3D-s nyomtatók elterjedésével költséghatékonyan lehet a játékokban részt vevő seregeket és a terepelemeket elkészíteni, így ennek a hadijátékos formának a további felvirágzása várható.

A másik - s egyben e publikáció alapját képező altípus - a hex-and-counter wargame, ami a térképi megjelenítést veszi alapul, és alkalmas egész hadszínterek, valamint az azokon folyó küzdelmek absztrakt ábrázolására. A játék alapját képező papírtérképek kis méretarányban, csak a domináns terepelemek megjelenítésével készülnek, amelyeket hexagonális rácshálózati felosztással látnak el. Ezek a hatszögletű kis mezők 2-15 kilométeres valós földrajzi területnek megfelelő részt fednek le. A mezőkben a harcoló és egyéb erőket néhány centiméteres, négyszögletes kartonlapokon található, NATOjelekkel ellátott jelzőkkel (counter) ábrázolják (a jelzők adatai általában az egységek főbb képességeit megjelenítő absztrakt értékeket - a tűzerőt, lőtávolságot vagy mozgási képességet - tartalmazzák). Az ilyen típusú hadijátékok léptéküknél fogva alkalmasak a logisztika, a tűztámogatás, a légierő és a kiszolgáló infrastruktúra, különleges müveletek és légideszantok, de akár a haditengerészet harcoló és ellátóelemeinek összhaderőnemi harcban való ábrázolására is. A bonyolult és költséges számítógépes infrastruktúrát tehát egy egyszerü térkép és a rajta elhelyezett egységeket jelölő kartonlapok helyettesítik, míg a harcértékeket és az összecsapások végeredményeit bonyolult algoritmusok helyett táblázatok, valamint a véletlenszerüséget és a kockázatvállalás mértékét jelző dobókockák helyettesítik. Mindezek alkalmasak arra, hogy a megfelelő katonai képességek és a terep alapos ismeretének megadása után helyesen és pontosan adják meg a várható összecsapások végeredményeit, amelyeknek spektruma a lövészzászlóaljak harcától a harcászati nukleáris és vegyi fegyverek megjelenítéséig terjedhet.

Az internet korát megelőző időkben a hobbihadijátékok pontossága nem érte el a katonai játékokét, hiszen nem rendelkeztek az azokéhoz mérhető pontos harcászattechnikai és eljárásbeli adatokkal, így a megadott kiinduló adatok pontatlanságánál fogva az eredmények sem közelíthették meg a valóságot. Manapság e források hozzáférhetősége jelentősen megnőtt, sőt bizonyos korszakokra vonatkozó adatok minősítési idejének lejárta után komoly adatbázisok szabadultak föl - itt elég csak a korábban általam is említett RAND-elemzések publikus részeinek hozzáférhetőségére gondolni. Ez hozzájárult ahhoz, hogy a civil felhasználásra készült wargame-ek pontosságukban napjainkra megközelítették a katonai felhasználásra készült társaikét, sőt rugalmasságuknál fogva bizonyos mértékben meg is haladták azokat. Szintén hozzájárult a fejlődéshez, hogy a katonák egy része hagyományosan a hadijátékos közösségek tagja volt, ${ }^{8}$ és a hidegháborús enyhülés hatására nagyobb arányban vehettek részt az új játékok tesztelésében, és szabadabban fejthették ki véleményüket azok pontosságával kapcsolatban is.

\footnotetext{
Különösen igaz ez a haditengerészetek tagjaira. A haditengerészeti hadijáték (naval wargame) a hadijátékok egyik altípusa, s résztvevői általában történelmi flották összecsapásait szimulálják. A haditengerészeti témájú játékok kis terepet, kevés modellt igényelnek, viszont bonyolult manőverek és olyan összecsapások eredményeinek vizsgálatára is alkalmasak, amelyekből a második világháborút követően nagyon kevés volt. Míg a szárazföldi haditechnikai eszközöket a hidegháború alatt folyamatosan, bár jellemzően helyi háborúkban alkalmazták, majd az ott szerzett tapasztalatok alapján fejlesztették őket, addig a flották közötti összecsapásra nagyon kevés kivételtől eltekintve nem volt példa, így a hadijátékok fontos szerepet töltöttek be a katonai vezetők képzése és az ellenséges eszközök becsült képességeinek modellezése során. Ismert tény, hogy a népszerü amerikai techno-thrilleríró, Tom Clancy több olyan művében, ami a haditengerészetek műveleteiről szól (például az 1984-es „Vadászat a Vörös Októberre,” vagy az 1986-os „Vörös vihar”) a hadijátékos társaival lejátszott öszszecsapások eredményeit ábrázolta irodalmi eszközökkel.
} 
A hadseregek számára készült klasszikus szimmetrikus, konfliktusközpontú hadijátékok a hidegháború végével folyamatosan háttérbe szorultak, s csak 2014 után kerültek újra előtérbe. ${ }^{9}$ Eddigre viszont a kitágult civil piac lehagyta a katonai fejlesztéseket.

\section{AZ AMERIKAI TENGERÉSZGYALOGSÁG KÖZELMÚLTBELI HADIJÁTÉK-TAPASZTALATAI}

Az Egyesült Államok katonai kiképzésében mindig is szerepeltek hadijátékok. ${ }^{10}$ A haditengerészet ebben különösen élen járt, ${ }^{11}$ de a krími és a dél-kínai tengeri események hatására a többi haderőnem is átértékelte a jövő konfliktusaira vonatkozó elméleteit. Ismét előtérbe került a hasonló vagy közel hasonló technikai színvonalon álló ellenséggel vívott hagyományos hadviselés lehetősége, ez pedig magával hozta a klasszikus konfliktusszimulátorok felé fordulást.

Nem kisebb személy, mint az Egyesült Államok védelmi miniszterhelyettese, Robert O. Work adott ki memorandumot 2015 februárjában, amelyben a változó biztonságpolitikai környezetre hivatkozva elöírta a hadijátékok mennyiségének és minőségének növelését, különösen a hivatásos tisztek képzéséért felelös intézményekben. ${ }^{12} \mathrm{Ez}$ a dokumentum közvetlenül vezetett a hadijátékok szerepének átértékeléséhez, valamint hozzájárult egy kreatívabb és támogatóbb szervezeti kultúra kialakulásához, amely napjainkra nemzetközi trenddé fejlődött. Ez érhető tetten a vezérkari iskolák és a törzstiszti tanfolyamok részére kiadott intézkedésekben is, amelyekben a hadijátékok előtérbe helyezéséről rendelkeznek. Ez pedig - nem meglepő módon - együtt járt a hadtörténelem (mint az ellenségek megértését segítő gyakorlati példatár és analógiagyüjtemény) felé fordulással. ${ }^{13}$ Összességében tehát

${ }^{9}$ A visszaszorulással egy időben megjelentek a társasjátékok népszerüségi hullámát meglovagló úgynevezett aszimmetrikus, vagy COIN (counter-insurgency, azaz felkelés elleni művelet) témájú játékok, amelyek az ellenség legyőzése helyett egy adott terület fölötti befolyás megszerzését helyezték előtérbe. Ezt katonai és diplomáciai, vagy gazdasági tevékenységek és intézkedések kombinációjával, realisztikus körülmények között kellett megszerezni. Ilyen játék például a GMT Games amerikai cég „A Distant Plain” nevủ játéka, amelyben négy játszható oldal (az amerikai, az afgán kormányzati, a tálibok és a hadurak egy csoportja) verseng az Afganisztán fölötti uralomért. A sorozat további részei a kubai forradalmat, a kolumbiai gerillák sorsát, a vietnámi háborút vagy éppen a francia-algériai eseményeket szimulálja. Ezek a játékok összetettségüknél fogva alkalmasak a politikai és katonai folyamatok modellezésére, újszerủ oldalról megközelítve a konfliktusszimulációt. GMT Games: A Distant Plain, 2018. https://www.gmtgames.com/p-656-a-distant-plain-3rd-printing.aspx (Letöltés időpontja: 2019. 05. 04.)

${ }^{10}$ Jeff Wong: Interwar-period gaming today for conflicts tomorrow, 2. rész. CIMSEC, 08. 05. 2017. http://cimsec. org/interwar-period-gaming-today-conflicts-tomorrow-press-start-play-pt-2/31712 (Letöltés időpontja: 2019. 05. 04.)

${ }^{11}$ A haditengerészet kiképzése és felkészítése jellegénél fogva nagyobb figyelmet szentel a hadijátékoknak, mint a többi haderőnem. Ök rendelkeznek a haderőnemek közül a legrészletesebb iránymutatás-gyüjteménnyel, amelyet a haditengerészet vezérkari iskolája, a Naval War College (NWC) hadijáték tanszéke (War Gaming Departement, WDG) adott ki. Shawn Burns (ed.): War Gamers' Handbook: A Guide for Professional War Gamers. US Naval War College, Newport, RI. https:/dnnlgwick.blob.core.windows.net/portals/0/NWCDepartments/ Wargaming\%20Department/WGD-HB---Complete-2.pdf?sr=b\&si=DNNFileManagerPolicy\&sig=f892NZP1 7WHNbSapI8ujWoG44y4NQRhBRooSPcwBrgs\%3D (Letöltés időpontja: 2019. 05. 04.)

${ }_{12}$ Robert O. Work: Memorandum to Pentagon Leadership on Wargaming. USNI News. 09. 02. 2015. https://news. usni.org/2015/03/18/document-memo-to-pentagon-leadership-on-wargaming. (Letöltés időpontja: 2019. 05. 04.)

${ }_{13}$ Az Amerikai Egyesült Államok nemzeti biztonsági stratégiája a hivatásos tisztek képzésével szemben támasztott követelmények között kiemeli a történelem ismeretének szükségességét is. Summary of the National Defence Strategy of the United States of America. Department of Defense, 2018, 8. https://dod.defense.gov/Portals/1/ Documents/pubs/2018-National-Defense-Strategy-Summary.pdf (Letöltés időpontja: 2019. 05. 04.) 
elmondható, hogy amikor a NATO vezető angolszász katonai hatalmai az utóbbi évtizedek felkelés elleni (COIN-) múveletei után találkoztak egy nagyszabású, konvencionális háború lehetőségével, az ellenség kihívására adott válaszként egyszerre fordultak - többek közt a hadijáték és a hadtörténelem felé.

Ennek a folyamatnak a részeként az amerikai tengerészgyalogság quanticói vezérkari iskoláján, a Marine Corps War College-ban (MCWAR) a közelmúltban stratégiai szintü hadijátékon alapuló, többnapos gyakorlatot hajtottak végre. ${ }^{14}$ A gyakorlat újszerüségét az adja, hogy nem egy belső, katonai hadijátékos rendszerben, hanem egy civil, kereskedelmi forgalomban kapható (commercial off the shelf-COTS) eszközzel, a GMT Games nevü amerikai cég Next War (Következő háború) sorozatával folytatták le. A sorozat szabályrendszere a lehető legrészletesebben igyekszik feldolgozni napjaink lehetséges konfliktusait, ${ }^{15}$ stratégiai szintű döntéshozatalra kényszeríti a résztvevőket, és két, egymással szemben álló csoport számára biztosít gyakorlási lehetőséget.

A hadijáték levezetője a kis létszámú tengerészgyalogos és egyéb haderőnemi tiszt számára három eltérő konfliktus egy időben, a közeli jövőben történő megvívását adta feladatul. A konfliktusok színtere Tajvan, Korea és a Baltikum volt. Ennek érdekében a Next War-sorozat három vonatkozó játékát vették elö, és játékonként két csoportot (összesen hat csoportot, két, egymással szemben álló oldalon elosztva) hoztak létre. A két, egymással szemben álló oldal az amerikai-NATO és az orosz-kínai tengely mentén oszlott meg. A játékban nyolc évnek megfelelő felkészülési időt és 200 milliárd dollár elkölthető pénzöszszeget adtak oldalanként, amelyet a csoportok a három jövőbeni hadszíntér között osztottak meg a döntésüknek megfelelő súlyozással. A pénz elköltéséhez a felkészítők egy több tucat eszközből és képességből összeállított listát adtak meg, amely a repülőgéphordozó-építéstől kezdve a diplomáciai kapcsolatokon át a kvantumszámítógépek és a kiberképességek fejlesztéséig igen széles skálát fedett le. ${ }^{16}$ Ezzel a szervezők olyan döntések meghozatalára késztették a résztvevőket, amely stratégiai gondolkodást, hosszú távú tervezést és a felsorolt képességek hatásának ismeretében való nagyfokú jártasságot várt el. Úgy vélem, ezeknek a döntéshozatali kritériumoknak inkább egy klasszikus vezérkari képzés szintje felel meg, nem pedig egy hadmüveleti vagy müveleti jellegü tanfolyam.

A forgatókönyv szerint az események elöször a résztvevők által fő hadszíntérként kezelt Európában vezettek nyílt háborúhoz. (Ez a hipotézis a RAND Corporation korábban idézett tanulmányából indult ki, amely a Baltikum irányába vezető stratégiai folyosó, a lengyelországi Suwałki területén elöbb fegyverkezési verseny kialakulását, majd nyílt konfliktus kitörését vizionálta.) Mindez lehetőséget teremtett az ázsiai hatalmaknak saját céljaik elérésére, így néhány nap különbséggel szintén háborúhoz vezetett az USA és szövetségesei ellen.

A hadijáték során az első néhány hét eseményeit játszották le. Ez idő alatt az Egyesült Államok és a NATO az első nap során közel 60 ezer fős veszteséget szenvedett, s ez a hét végére megközelítette oldalanként a 150 ezer föt. ${ }^{17}$ Összességében a játék tapasztalatai a veszteségek terén az első világháborúra jellemző szinthez közelítettek, amelynek pótlására és a müveleti tempó fenntartására egyik részt vevő állam sem állt készen, így nagyon hamar

\footnotetext{
${ }^{14}$ James Lacey: How does the next great power conflict play out? Lessons from a wargame. War on the Rocks, 22. 04. 2019. https://warontherocks.com/2019/04/how-does-the-next-great-power-conflict-play-out-lessonsfrom-a-wargame/ (Letöltés idöpontja: 2019. 05. 04.)

${ }_{15}$ A Next War-sorozat tagjai között van többek közt a Korea, az India-Pakistan, a Taiwan és a Poland.

${ }^{16}$ Lacey: i. m.

${ }^{17}$ Lacey: i. m.
} 
elökerült a korlátozott nukleáris háború lehetősége végső megoldásként. Ez ráébresztette a tanfolyam résztvevőit a modern gépesített háborús müveletek tényleges méreteire és a korábbi évtizedek COIN-tapasztalatai alapján megállapított veszteségekkel szembeni türéshatárok tarthatatlanságára.

A wargame során mindenki aktívan részt vett a döntések megvitatásában, a hadtörténelemből vett analógiák alapján igyekeztek megbecsülni a tevékenységük következményeit és ellenfeleik lehetséges céljait. Az aktív részvétel hatására az elért eredmények és tapasztalatok sokkal mélyebben rögzültek a résztvevőkben, mintha csak passzív szemlélői lettek volna az eseményeknek - így tulajdonképpen egy gyakorlati foglalkozás résztvevői lehettek, amelyet kis forrás- és anyagigény mellett, tanteremben is meg lehetett tartani.

Az amerikai eredmények azt mutatják, hogy a gyakorlati foglalkozásoknak a vezérkari képzések szintjén is van létjogosultságuk, ${ }^{18}$ sőt az aktív, gyakorlatközpontú tanulással jobb eredményeket lehet elérni, mint a hagyományos tantermi foglalkozásokkal, nem beszélve arról, hogy a hallgatók mindegyike kifejezetten élvezte a hadijátékot.

\section{KATONAI FELHASZNÁLÁSRA ALKALMAS, KERESKEDELMI FORGALOMBAN KAPHATÓ HADIJÁTÉKOK}

A wargame-piac rendkívül széles, szinte minden témában tálalhatunk hadijátékokat. Ezek nem mindegyike alkalmas azonban katonai felhasználásra. Az elmúlt években egyre több hadsereg kezdett alkalmazni civilek számára készült hadijátékot kiképzési célra, ami a törzsgyakorlás mellett kiválóan alkalmas a hadtörténelmi ismeretek elmélyítésére, ezen keresztül pedig a katonaősök hagyományának ápolására is. ${ }^{19}$ Érdekességképpen jegyzem meg, hogy ezek az egyedi gyakorlatok főként a témájuk miatt jelentettek változatosságot, $\mathrm{s}$ ez által komoly érdeklődést váltottak ki a résztvevőkben.

A továbbiakban az amerikai tengerészgyalogosok által is alkalmazott hadijátékok leírásával szeretném illusztrálni, mire képes egy modern, kereskedelmi forgalomban is kapható wargame, nagyjából 80-100 dolláros áron.

A GMT Games komplex, hadmüveleti és hadászati szintü, hadtörténelmi témájú játékairól ismert. Az általuk kifejlesztett Next War-sorozat ezek közül is kiemelkedik a valóságot megközelítő részletességével. A játékok elkészítéséhez az internetes adatbázisokon túl az amerikai haderő szabályzatait és nyilvános elemzéseit használják fel, s ezeket egészítik ki a civil kutatóközpontok publikációival is. Összességében elmondható, hogy a nyíltan hozzáférhető forrásokat megfelelően dolgozzák fel, és 2017-ben piacra dobták a sorozat eddigi legkiforrottabb részét, a Next War: Polandet. ${ }^{20}$

\footnotetext{
${ }^{18}$ Lacey: i. m.

19 A varsói székhelyű Taktyka i Strategia nevü lengyel cég nagy számban gyárt hadmủveleti szintű játékokat, amelyeknek széles palettája az ókortól napjainkig terjed. A nyíltan elérhető Facebook-oldalukra gyakran tesznek fel képeket, ahol a lengyel dandártörzsekkel (többek közt a 7. és 12. dandárok vezetésével) az 1939-es lengyel hadjárat egyes csatáinak, hadmüveleteinek a mai törzsmunka módszerével (Military Decision Making Process - MDMP), modern térképeken való újrajátszását végzik. Ez természetesen az egyszerü tervezőmunka gyakorlásán túl a saját hadtörténelmük eseményeinek alaposabb megismerését is jelenti, amely hozzájárul a hagyományok ápolásához is, és némi változatosságot jelent a katonáknak. Ez egy újabb, látványos példa arra, hogy egy kelet-európai hadsereg a hadtörténelem és a hadijáték mélyebb integrálására kötelezi el magát. https:// taktykaistrategia.pl/en/ (Letöltés időpontja: 2019. 05. 04.)

${ }^{20}$ Az ismertető a „Next War: Poland” nevű hadijáték szabálykönyve alapján készült. Next War: Poland. GMT Games, 2017. https://www.gmtgames.com/p-569-next-war-poland.aspx (Letöltés időpontja: 2019. 05. 04.)
} 
A Next War: Polandben a cselekvési sor a követhetőség miatt körökre van osztva, amelyben egy kör 3-4 napnak megfelelö időtartamot fed le. A játék két nagy méretű keménypapír térképet tartalmaz. Az egyik egy hexagonális ráccsal felülnyomott, stilizált Lengyelország hadmüveleti térkép, amely a Balti-tengertől Varsóig terjedő területet ábrázolja, ahol egy hatszög 12 kilométert jelent. A másik térkép egy stratégiai térkép, amely a Balti-tenger medencéjét ábrázolja, Finnországtól Németországig. Ez utóbbi hivatott a balti országok területén zajló stratégiai müveletek és a haditengerészeti tevékenységek, partraszállások hátterét adni - ahogyan ezen szerepelnek az oroszországi bázisokra telepített nagy hatótávolságú fegyverek is.

A két térképet több tucat állam hadseregét megjelenítő, NATO-jelekkel ellátott kis jelzők (counter) egészítik ki, amelyek száma megközelíti az ezer darabot. Ezek a lengyel fegyveres erők egészét, több amerikai hadosztályt és a NATO Északkeleti Többnemzeti Hadtestének, valamint Gyorsreagálású Erőinek dandárszintű alakulatait ábrázolják. Az ellenséget az orosz és fehérorosz erők ezredszintü alakulatai adják. Mindezeket több tucat repülőosztály és helikopterzászlóalj egészíti ki, amelyek mellett a különleges müveleti csoportok is megjelennek. Ez utóbbiak feladata közé tartozik a vezetési pontok, légvédelmi eszközök, stratégiai fontosságú átkelők, hidak, illetve a légierőt kiszolgáló infrastruktúra szabotálása, amely nagyban befolyásolja a müveletek menetét. Hangsúlyos szerepet kap még a logisztika, annak is a hadászati-hadmüveleti szintü tervezési aspektusa, amely lefedi a hadmüveleti terület utánpótlási bázisainak kijelölését, utánpótlási útvonalak fenntartását, a hadászati szállítás és utánpótlás kérdéseit is.

A játék alapvetően a következő stratégiai döntések elé állítja a résztvevőket: az időkényszerben (az erősítések beérkezése az amerikai kontinensröl) milyen eröket koncentráljanak a Baltikumba és milyeneket Lengyelországba, hogyan sikerülhet bevonni a küzdelembe a semleges skandináv államokat, mi lesz a különleges erők célpontja, mikor kezdik meg a légi müveleteket, vagy hogy a NATO-erők hol és mikor veszik fel a harcérintkezést? A légierők irányítói számára a szárazföldi erők támogatása vagy a légi fölény kivívása lehet a fó cél - ez utóbbit az ellenséges légierő és annak kiszolgáló infrastruktúrája pusztításával, SEAD-müveletekkel, ${ }^{21}$ elektronikai harccal, a rendelkezésre álló standoff fegyverekkel, vagy a kibertérben zajló müveletekkel, esetleg a különleges erők alkalmazásával lehet elérni. ${ }^{22}$

Ebböl is látszik, hogy a játék kellően összetett; megjelennek benne napjaink katonai müveleteinek aspektusai, de kellő absztrakcióval, hogy a játék ne váljon harcászati kérdésekbe bonyolódó küzdelemmé, amely lelassítaná a játék menetét (a cirkálórakéták és harcászati tömegpusztító fegyverek például önálló csapásmérő képességként jelennek meg, de a drónok és egyéb pilóta nélküli eszközök egyszerűen be vannak építve az ábrázolt egységek értékeibe vagy a felderítőrendszer ábrázolásába).

\section{A CIVIL HADIJÁTÉKOK ALKALMAZHATÓSÁGA A HAZAI FELSŐFOKÚ VEZETŐKÉPZŐ TANFOLYAMON}

Napjainkban a magyar katonai vezetők és törzstisztek ritkán hajtják végre feladatukat tisztán nemzeti kötelékben. Szövetségi szerepvállalásunkból következik, hogy katonáink nemzetközi

\footnotetext{
${ }^{21}$ A SEAD (Suppression of Enemy Air Defences) jelentése: az ellenséges légvédelem elnyomása.

${ }^{22}$ Az amerikai gyakorlat során a NATO légierő az első hét szárazföldi mủveleteibe nem volt képes döntően beavatkozni, mert a légi fölény kivívása volt a feladata. Ez a szárazföldi csapatok számára további súlyos veszteségek elszenvedését okozta.
} 
gyakorlatokon vesznek részt, NATO-parancsnokságokon tervezö- és - adott esetben - döntéshozó pozícióba kerülnek. A katonai felső vezetés számára a gyakorlatban megszerzett tudás, a stratégiai döntéshozatalban szerzett tapasztalat különösen értékes - annak első kézből való megszerzése pedig nem könnyü, mivel a Magyar Honvédség rendeltetéséből és adottságaiból következően ilyen müveletekben korlátozottan vesz részt. A hadijátékok azonban bárki számára elérhető, valóságot megközelítő tapasztalatszerzésre adnak lehetőséget. Mindezeken túl azonnali visszacsatolás érkezik a meghozott döntésekröl, amely objektív, tehát a hiba lehetőségét kizáró módon áll rendelkezésre. Az eredmények elemzése komoly tapasztalatfeldolgozásra is lehetőséget ad.

Az itt korábban bemutatott civil hadijáték segítségével nemzetközi diplomáciai, a haditengerészetet is magában foglaló összhaderőnemi tervezési és együttmüködési, valamint hadmüveleti szintü harcvezetési tapasztalatra tehetnek szert leendő felső vezetőink, viszonylag olcsón, kis erőforrás- és infrastruktúra-igénnyel.

Úgy vélem, célszerü lenne az NKE HHK Katonai Felsővezető Szakirányú Továbbképzési Szak, közkeletű nevén a felsőfokú vezetőképző tanfolyam gyakorlatközpontúságát még inkább fokozni, és valós stratégiai döntéshozatali kényszerbe hozni a gyakorlatokon részt vevőket. A végrehajtás során - létszám függvényében - két vagy három csoport létrehozását javaslom, amelyek egymás ellen kompetitíven, vagy egymással kényszerü együttmüködésben, folyamatos egyeztetések mellett tevékenykednek. A csoportokon belül lehetséges haderőnemi felelösöket kijelölni, ami tovább növeli a valóságot megközelítő helyzet kialakítását, és további belső kommunikációra és kompromisszumos döntéshozatalra kényszeríti a résztvevőket. A csoportok közti egészséges versengés és a saját cél elérésére való törekvés alapvetően növelheti a résztvevők aktivitását, érintetté tenné őket a közös gyakorlati tanulás folyamatának sikerében.

A gyakorlatok időtartama 4-5 egymást követő napot fedhetne le, amelyből 2-3 nap lenne a tényleges játék (ez hadműveleti időben 4-6 hetet jelentene), a többi a helyzetbeállításra, a szabályok tisztázására és az értékelésre fordítandó idő. Ezek során volna lehetőség az absztrakcióból adódó sajátosságok, a rendelkezésre álló képességek tisztázására. Nem szabad eltekinteni a játékot követő értékelésről sem, külön hangsúlyt helyezve az együttmüködés megvalósulására. A gyakorlat természetesen a rendelkezésre álló hadijátékra alapozva, alapvetően nyílt adatokkal és forrásokkal dolgozna.

A gyakorlat legfontosabb és legnagyobb költségü kiadását a játék néhány példányának beszerzése jelenti. A részt vevő csoportok külön terembe történő elkülönítése után részükre térképek kiadása szükséges (ezek lehetnek a játék mellékelt térképei, amelyeket digitálisan a gyakorlatra kell szabni és sokszorosítani, vagy JOG-A és/vagy JOG-G térképek, ${ }^{23}$ esetleg TPC térképek ${ }^{24}$ ), amelyek háttérként szolgálnak a müveleti tervezés során. A feladatszabások írásban való elkészítésére, az eredmények ismertetésére minimális, nyomtatóval támogatott informatikai biztosítás szükséges, az értékelés pedig egy diasorral támogatott előadás keretében történhetne meg.

A hadijáték léptékéből adódik, hogy a feladatok és az erök egymás mellé rendelése a fö cél, nem pedig a harc megvívása a hangsúlyos, mint a harcászati vagy hadmúveleti szintü játékok esetén - ezek modellezésére, az eredmények kiszámítására egy gyakorlatvezető és

\footnotetext{
${ }^{23}$ A JOG-ok (Joint Operational Graphics) a NATO-ban rendszeresített 1:250 000 méretarányú együttműködési térképek. A JOG-Air a légi együttműködési térkép, a JOG-Ground pedig a szárazföldi együttműködési térkép.

${ }^{24}$ A TPC-k (Tactical Pilotage Chart) alapvetően a katonai légi közlekedés számára készített 1:500 000 méretarányú térképek.
} 
kis létszámú segítő törzs is elegendő, akik az eredeti játékhoz mellékelt jelzők segítségével modellezik az események kimenetelét. Ugyanez a törzs hajtaná végre az értékelést is. Ez utóbbit a játék forgatókönyve szerinti győzelmi kondíciók (terület birtokbavétele, szemben álló erők megsemmisítése stb.) alapján, objektíven kell elvégezni, illetve ki kell egészíteni a döntéshozatal minőségének vizsgálatával.

Kiemelt fontosságú, hogy a játék - annak vetélkedő jellege ellenére - egy tanulási folyamat, amely minden részt vevő csoport számára közös tapasztalatot kínál, így a győztes/ vesztes felek túlzottan pozitív/negatív értékelése nem szerencsés - a hadijáték tanfolyami felhasználása az oktatás fontos eszköze, és a megszerzett tudás rögzítésére szolgál. Az ilyen jellegü gyakorlat értékelésének célja az esetleg a képzés során korábban fel nem tárt tervezési és vezetési hiányosságok azonosítása, valamint a felek számára rendelkezésre álló képességek hatékony felhasználásának mérése.

\section{ÖSSZEGZÉS}

Mint látható, a hadijáték viszonylag kevés emberi és anyagi erőforrást igénylö, azonban aktív részvételt és hatékony csoportmunkát megkövetelö, kompetitív gyakorlattípusként hasznosan és különösebb nehézség nélkül integrálható része lehetne a katonai felsővezetö-képzésnek. Napjaink hobbi hadijátékai magas komplexitásuknál és a valóságot megközelítő jellegüknél fogva kiváló pedagógiai eszközt jelentenének a tanfolyami rendszerekben tanulók képzésére is. Felhasználásuk jelen formájukban föleg az oktatási intézményekben indokolt, amelyböl logikusan következik, hogy nem alkalmasak mindenfajta (például szervezeti egységeket, parancsnokságokat érintő komplex) gyakorlatoztatására, ${ }^{25}$ mert azok más jellegü hadijátékot igényelnek. Mindez azt jelenti, hogy szükséges az oktatási intézményeken kívül is létrehozni vagy továbbfejleszteni már meglévő kutatócsoportokat, amelyek kifejezetten a kísérleti tanulási módszerek fejlesztését és a hadijátékok levezetését végzik, lehetőség szerint csoportmunkával, kompetitív módon.

Ezen túl, a megszerzett tapasztalatok függvényében célszerü volna a hadmüveleti és a harcászati szintü, akár a modern magyar hadtörténet eseményeire épülő hadijátékokra alapozott gyakorlatok, és ezzel összefüggésben nagyobb óraszámú, praktikumra épülő hadtörténelmi foglalkozások bevezetése a katonai vezető MSc és BSc képzésekben is, oldva a tantermi előadások monotonitását. Ezzel az alapoktól lehetne létrehozni vagy újjáépíteni egy modern szemléletü, a NATO-ban az elmúlt években kialakult és jól müködő trendekhez hasonlóan, a hadijátékokat pedagógiai és kiképzéstechnikai eszközként önállóan alkalmazni képes, változatos döntéshozatali eljárásokban jártas tisztikart.

Mint látható, ez sem anyagilag, sem infrastrukturálisan nem terhelné meg a Magyar Honvédséget, de mindenképpen új szemléletmód elfogadását követeli meg. A megfelelő keretek kialakítását és a gyakorlati alapok lefektetését követően viszonylag kis befektetéssel komoly előrelépést lehetne elérni a katonai hagyományok ismeretében és ápolásában, valamint az állomány döntéshozatali képességének, önállóságának, együttmüködési képességének fejlesztésében. Jelenleg a lemaradásunk még csak néhány év, de a lengyel példából látható, hogy az amerikai és brit minta hatására már régiónk hadseregei is elkezdték átvenni az újításokat.

${ }^{25}$ Lacey: i. m. 


\section{FELHASZNÁLT IRODALOM}

Burns, Shawn (ed.): War Gamers' Handbook: A Guide for Professional War Gamers. US Naval War College, Newport, RI. https://nnlgwick.blob.core.windows.net/portals/0/NWCDepartments/ Wargaming\%20Department/WGD-HB---Complete-2.pdf?sr=b\&si=DNNFileManagerPolicy\& sig=f892NZP17WHNbSapI8ujWoG44y4NQRhBRooSPcwBrgs\%3D

Development, Concepts and Doctrine Center (Ministry of Defence): Wargaming Handbook. LCSLS Headquarters and Operations Centre, Bicester, 2017. https://assets.publishing.service.gov.uk/ government/uploads/system/uploads/attachment_data/file/ 641040/doctrine_uk_wargaming_ handbook.pdf

GMT Games: A distant plain, 2018. https://www.gmtgames.com/p-656-a-distant-plain-3rd-printing.aspx GMT Games: Next War: Poland, 2017. https://www.gmtgames.com/p-569-next-war-poland.aspx

Johnson, Michael - Shlapak, David A.: Reinforcing Deterrence on NATO's Eastern Flank. Wargaming the Defense of the Baltics. Rand, 2016. https://doi.org/10.7249/RR1253

Lacey, James: How does the next great power conflict play out? Lessons from a wargame. War on the Rocks, 22. 04. 2019. https://warontherocks.com/2019/04/how-does-the-next-great-power-conflictplay-out-lessons-from-a-wargame/

Pogácsás Krisztián: Terepasztalos parancsnoki hadijáték, avagy a parancsnoki döntéshozatal és harcászati szemlélet fejlesztésének eszköze. Seregszemle, XI. évf. 2013/2-3. http://bocskaikonyvtar. hu/images/emedia/PogacsasK_terepasztal2.pdf

Wong, Jeff: Interwar-period gaming today for conflicts tomorrow, 2. rész. CIMSEC, 08. 05. 2017. http://cimsec.org/interwar-period-gaming-today-conflicts-tomorrow-press-start-play-pt-2/31712

Work, Robert O.: Memorandum to Pentagon Leadership on Wargaming. USNI News, 09. 02. 2015 https://news.usni.org/2015/03/18/document-memo-to-pentagon-leadership-on-wargaming https://taktykaistrategia.pl/en/ 